University of Nebraska - Lincoln

DigitalCommons@University of Nebraska - Lincoln

Agronomy \& Horticulture -- Faculty Publications

Agronomy and Horticulture Department

$5-1977$

Callus and Suspension Cultures of Melilotus alba Tissues and

Cells

Tomoaki Taira

University of Manitoba

Francis A. Haskins

University of Nebraska-Lincoln, fhaskins@neb.rr.com

Herman J. Gorz

Uinted States Department of Agriculture

Follow this and additional works at: https://digitalcommons.unl.edu/agronomyfacpub

Part of the Plant Sciences Commons

Taira, Tomoaki; Haskins, Francis A.; and Gorz, Herman J., "Callus and Suspension Cultures of Melilotus alba Tissues and Cells" (1977). Agronomy \& Horticulture -- Faculty Publications. 262.

https://digitalcommons.unl.edu/agronomyfacpub/262

This Article is brought to you for free and open access by the Agronomy and Horticulture Department at DigitalCommons@University of Nebraska - Lincoln. It has been accepted for inclusion in Agronomy \& Horticulture -Faculty Publications by an authorized administrator of DigitalCommons@University of Nebraska - Lincoln. 


\title{
Callus and Suspension Cultures of Melilotus alba Tissues and Cells ${ }^{1}$
}

\author{
Tomoaki Taira, F. A. Haskins, and H. J. Gorz ${ }^{2}$
}

\begin{abstract}
These studies were designed to define conditions for the satisfactory establishment and maintenance of sweetclover (Melilotus alba Desr.) callus and cell suspension cultures.

Callus was derived from cotyledons and hypocotyls of germinated sweetclover seeds of various genotypes. Under the conditions used, 2,4-dichlorophenoxyacetic acid (2,4D) was effective (optimal concentration ca $1 \mathrm{mg} / \mathrm{liter}$ ) for callus induction; other auxins and cytokinins were ineffective. Best callus growth occurred at a 2,4-D concentration of about $2 \mathrm{mg} / \mathrm{liter}$ and a sucrose concentration of $2 \%$. Callus growth was improved by casein hydrolysate $(0.9 \mathrm{~g}$ /liter). Glutamic acid appeared to be the most important single amino acid in the hydrolysate.

Suspension cultures failed to survive in the absence of 2,4-D. Highest cell numbers and final/initial cell-count ratios were observed at a $2,4-D$ concentration of $0.2 \mathrm{mg} /$ liter. The callus type that yielded highest cell counts in suspension culture was friable, but friable growth type on agar was not always associated with highest cell numbers in suspension cultures. Inoculum size was important in determining the performance of suspension cultures, possibly because of the influence of "conditioned" medium. Attempts to regenerate intact plants from the cultured callus tissues were not successful.
\end{abstract}

Additional index words: Auxin, Cytokinin, Sweetclover, Tissue culture.

$I^{\mathrm{N}}$ NTEREST in the culture of tissues and cells of various crop plants has increased greatly in the past decacle. Such cultures offer many advantages for certain types of genetic, physiological, and biochemical studies. Also, as discussed in Bottino's recent review (2), such cultures offer considerable potential for use in plant breeding programs. Unfortunately, as Street (17) has stated, many aspects of plant cell culture remain empirical, and the development of satisfactory procedures for culturing cells of a particular kind of plant typically involves a substantial amount of trial and error.

The experiments reported in this paper were designed to determine the conditions required for the induction and maintenance of white sweetclover (Melilotus alba Desr.) callus and for the suspension culture of cells derived from this callus. At the time these studies were initiated, very few reports of the

${ }^{1}$ Contribution from the ARS-USDA, and the Nebraska Agric. Fxp. Stn., Lincoln. Data are from a thesis submitted by the senior author to the Graduate College, Univ. of Nebraska-Lincoln, in partial fulfillment of the requirements for the Ph.D. degree. Published as Paper No. 5097, Journal Series, Nebraska Agric. Exp. Stn. Received 19 Ang. 1976.

${ }^{2}$ Postdoctoral fellow, Dep. of Plant Science, Univ. of Manitoba, Winnipeg; Foundation Professor of Agronomy, Univ. of Nebraska-Lincoln; and research geneticist, ARS-USDA, and professor, Lincoln, NE 68583 , respectively.

${ }^{3}$ Mention of a trademark or proprietary product does not constitute a guarantee or warranty of the product by the USDA nor imply its approval to the exclusion of other products that may also be suitable. culture of sweetclover cells and tissues were found in the literature. Those reports that were found ( 11 , 13, 14) did not deal extensively with the conditions required for satisfactory growth. Two more recent reports $(3,4)$ provide some added information concerning the influence of varying cultural conditions on the growth callus derived from sweetclover roots, but these reports and the present study do not overlap extensively.

\section{MATERIALS AND METHODS}

The tissues used for callus initiation were obtained from very young seedlings of white-flowered sweetclover. Most of the seedlings represented four closely related, highly inbred strains of the $C u C u B B, C u C u b b, c u c u B B$, and $c u c u b b$ genotypes. Compared to $C u C u$ plants, cucu plants are low in content of glucosidically bound $c i s$ - and trans-o-hydroxycinnamic acid (8). Similarly, cell-free preparations of $b b$ plants are extremely low in $\beta$-glucosidase activity in comparison with preparations of $B B$ plants (10). The glucosides of cis- and trans-o-hydroxycinnamic acid are intermediates in the biosynthesis of coumarin, and the enzyme, $\beta$-glucosidase, catalyzes one of the steps in the coumarin pathway (8). Therefore, it was thought that callus and suspension cultures differing as to the $C u / c u$ and $B / b$ genes might be useful in studies of coumarin biosynthesis. Callus also was derived from seedlings of a dwarf strain, genotype $d w d w$ (7). With respect to the $C u / c u$ and $B / b$ genes, the $d w d w$ strain was $C u C u B B$; with respect to the $D w / d w$ alleles, the other four strains were $D w D w$.

After a considerable amount of preliminary testing, the following procedure was adopted for callus induction. Seeds were hand-scarified, immersed in tap water in Erlenmeyer flasks, and shaken at low speed on a New Brunswick Gyrotory $y^{3}$ shaker until they germinated. The water was changed at least once each day during this period to reduce microbial growth. Germinated seeds were washed with several changes of tap water, after which portions of cotyledions and hypocotyls were excised. These explants were immersed for $1 \mathrm{~min}$ in $70 \%$ ethyl alcohol, rinsed three times with deionized distilled water, immersed for $7 \mathrm{~min}$ in Clorox (sodium hypochlorite; diluted 1:3 with water), and rinsed seven times with sterile deionized distilled water. The explants were then transferred to agar slants.

Fox's medium (5), somewhat modified, was used for maintenance as well as induction of callus. This medium was selected for routine use because it supported the growth of sweetclover callus somewhat better than the media of Blaydes (1), Gamborg (6), or Linsmaier and Skoog (12), or White's medium as modified by Street and McGregor (18). Composition of the basal medium was as follows (concentrations are in $\mathrm{mg} /$ liter): $\mathrm{Na}_{2} \mathrm{HPO}_{4} \cdot 7 \mathrm{H}_{2} \mathrm{O}-50 ; \mathrm{KH}_{2} \mathrm{PO}_{4}-250 ; \mathrm{KNO}_{3}-1000 ; \mathrm{NH}_{4} \mathrm{NO}_{3}-1000 ;$ $\mathrm{KCl}-50 ; \mathrm{MgSO}_{4} \cdot 7 \mathrm{H}_{2} \mathrm{O}-300 ; \mathrm{Ca}\left(\mathrm{NO}_{3}\right)_{2} \cdot 4 \mathrm{H}_{2} \mathrm{O}-500 ; \mathrm{MnSO}_{4} \cdot \mathrm{H}_{2} \mathrm{O}-$ $10 ; \quad \mathrm{ZnSO}_{4} \cdot 7 \mathrm{H}, \mathrm{O}-3 ; \quad \mathrm{H}_{3} \mathrm{BO}_{3}-3 ; \quad \mathrm{KI}-0.8 ; \quad \mathrm{Na}_{2} \mathrm{MoO}_{4} \cdot 2 \mathrm{H}_{2} \mathrm{O}-0.25 ;$ $\mathrm{CuSO}_{1} \cdot 5 \mathrm{H}_{2} \mathrm{O}-0.025 ; \mathrm{CoCl}_{2} \cdot 6 \mathrm{H}_{2} \mathrm{O}-0.025$; Na-Fe-EDTA-12.5; thiamine-HCl-1; nicotinic acid-0.5; pyridoxine-HCI-0.5; myoinositol-100; casein hydrolysate-1000 (unless otherwise stated); sucrose-25000 (unless otherwise stated); and for solid medium, agar-7500. The salts used in this basal medium were of reagent grade. Various auxins and cytokinins were added to the medium as indicated in the subsequent text and tables. For routine use, the auxin was 2,4-dichlorophenoxyacctic acid $(2,4-D)$, which was added to solid media at a concentration of $2 \mathrm{mg} /$ liter and to liquid media at $0.2 \mathrm{mg} / \mathrm{liter}$. Both agar and liquid media were adjusted to pH 6.0 with $0.5 \mathrm{~N}$ HCl or $0.5 \mathrm{~N} \mathrm{NaOH}$. Ten-milliliter portions of the agar media were dispensed into test tubes $(20 \times 180 \mathrm{~mm})$. For liquid cultures, $30-$ or $40-\mathrm{ml}$ portions werc usually used in 125 - or $250 \cdot \mathrm{ml}$ Erlenmeyer flasks. All media were autoclaved for $15 \mathrm{~min}$ at $115 \mathrm{C}$. 
Table 1. Influence of 2,4-D with and without kinetin, on the induction of callus from $\mathrm{CuCuBB}$ seedlings. Observations were made 15 days after cotyledons were excised from seedlings.

\begin{tabular}{|c|c|c|c|c|}
\hline \multicolumn{2}{|c|}{ Concentration } & \multirow{2}{*}{$\begin{array}{c}\text { No. of } \\
\text { explants }\end{array}$} & \multirow{2}{*}{$\begin{array}{c}\text { Percentage } \\
\text { callus induction }\end{array}$} & \multirow{2}{*}{$\begin{array}{l}\text { Condition } \\
\text { of callus } \dagger\end{array}$} \\
\hline 2,4-D & Kinetin & & & \\
\hline \multicolumn{5}{|c|}{ - $\mathrm{mg} / \mathrm{liter}-$} \\
\hline 0 & 0 & 18 & 0 & 0 \\
\hline 0.05 & 0 & 20 & 0 & 0 \\
\hline 0.10 & 0 & 20 & 15.0 & 1.2 \\
\hline 0.50 & 0 & 18 & 44.4 & 2.3 \\
\hline 1.0 & 0 & 20 & 100.0 & 3.6 \\
\hline 5.0 & 0 & 20 & 60.0 & 2.5 \\
\hline 10.0 & 0 & 20 & 25.0 & 1.8 \\
\hline 0 & 1.0 & 18 & 0 & 0 \\
\hline 0.05 & 1.0 & 20 & 0 & 0 \\
\hline 0.10 & 1.0 & 20 & 40.0 & 1.4 \\
\hline 0.50 & 1.0 & 20 & 65.0 & 3.1 \\
\hline 1.0 & 1.0 & 20 & 100.0 & 3.7 \\
\hline 5.0 & 1.0 & 20 & 70.0 & 2.9 \\
\hline 10.0 & 1.0 & 20 & 30.0 & 2.1 \\
\hline
\end{tabular}

† Scored visually on the following scale: $0=$ No growth; 1 - Poor; $2=$ Moderate; $3=$ Good 4 = Excellent

Table 2. Designation and source of various sweetclover callus tissues. The MY designation indicates a medium yellow callus color; $W$ indicates white.

\begin{tabular}{lll}
\hline & \multicolumn{2}{c}{ Source of callus } \\
\cline { 2 - 3 } Callus designation & Genotype & Tissue \\
\hline C1MY & CuCuBB & Cotyledon \\
C2MY & CuCubb & Cotyledon \\
C3W-friable & cucuBB & Cotyledon \\
C4MY & $c u c u b b$ & Cotyledon \\
H4W-friable & $c u c u b b$ & Hypocotyl \\
C5W-friable & $d w d w$ & Cotyledon \\
\hline
\end{tabular}

Cultures on agar were incubated in the dark. Suspension cultures were incubated under subdued fluorescent light on either a Gyrotory shaker $(160 \mathrm{rpm})$ or a reciprocating shaker (100 cycles $/ \mathrm{min}$ ). All cultures were incubated at room temperature $(25 \pm 2 \mathrm{C})$

In general, callus growth was expressed as the growth ratio (final fresh weight/initial fresh weight). Actual weights of the callus portions used for inoculation (i.e. initial fresh weights) ranged from about 80 to $100 \mathrm{mg}$. A haemocytometer was used for counting cells in the suspension cultures. Most of the data were subjected to analysis of variance techniques, and Duncan's multiple range test was used to compare treatment means at the $5 \%$ probability level. Standard errors were calculated for the mean counts of cells and cell clumps included in Table 7.

\section{RESULTS AND DISCUSSION}

\section{Callus Induction on Solid Medium}

In preliminary tests, cotyledons of the $C u C u B B$, $C u C u b b$, cucuBB, and cucubb genotypes all served well as sources of callus. The $C u C u B B$ genotype was used in further tests of the effects of different auxins and cytokinins on callus induction. Three auxins, indoleacetic acid (IAA), napthaleneacetic acid (NAA), and 2,4-D were individually tested at a concentration of $2 \mathrm{mg}$ /liter; only 2,4-D was found to be effective at this concentration. The cytokinins, kinetin and 6-benzyladenine, each tested at $1 \mathrm{mg} /$ liter, were ineffective as callus inducers, as was coconut milk (15\% $\mathrm{v} / \mathrm{v})$.

Concentrations of 2,4-D, ranging from 0 to $10 \mathrm{mg} /$ liter with and without kinetin ( $1 \mathrm{mg} /$ liter), were tested for effectiveness in inducing callus formation from cotyiedonary tissue. Of the concentrations tested, $1 \mathrm{mg} /$ liter was the most effective, both in the absence
Table 3. Influence of 2,4-D concentration on the growth ratio of C2MY callus (three replications, cultured 30 days). Initial fresh weights were approximately $100 \mathrm{mg}$.

\begin{tabular}{cc}
\hline 2,4-D concentration & Growth ratio \\
\hline mg/liter & \\
0 & $8.0 \mathrm{c}^{*}$ \\
0.01 & $7.9 \mathrm{c}$ \\
0.05 & $8.2 \mathrm{c}$ \\
0.1 & $8.2 \mathrm{c}$ \\
0.5 & $17.9 \mathrm{~b}$ \\
1.0 & $15.6 \mathrm{~b}$ \\
2.0 & $35.4 \mathrm{a}$ \\
5.0 & $16.0 \mathrm{~b}$ \\
\hline
\end{tabular}

* Numbers followed by the same letter are not significantly different at the $5 \%$ probability level.

Table 4. Influence of sucrose concentration on growth ratio of C1MY callus (10 replications, cultured 25 days). Initial fresh weights were approximately $80 \mathrm{mg}$.

\begin{tabular}{cc}
\hline Sucrose concentration & Growth ratio \\
\hline$\%$ & \\
0.25 & $8.7 \mathrm{c}^{*}$ \\
1.0 & $15.4 \mathrm{~b}$ \\
2.0 & $18.3 \mathrm{a}$ \\
3.0 & $18.3 \mathrm{a}$ \\
4.0 & $7.4 \mathrm{~d}$ \\
8.0 & $4.4 \mathrm{e}$ \\
\hline
\end{tabular}

* Numbers followed by the same letter are not significantly different at the $5 \%$ probability level.

and presence of kinetin (Table 1). Kinetin appeared to increase induction somewhat, especially at 2,4-D concentrations of 0.1 and $0.5 \mathrm{mg} /$ liter. The callus formed in the presence of 2,4-D plus kinetin had a distinct yellow color in contrast to the medium yellow color typical of callus induced by 2,4-D alone. Results obtained with hypocotyl tissue were generally similar to those with cotyledons. With both types of tissue, callus induction usually occurred over the entire surface of the explants.

Designations and sources of the callus tissues used in the remainder of this study are shown in Table 2.

\section{Callus Growth on Solid Medium}

Response to Auxins. Strain C2MY callus was cultured for 15 days on 2,4-D-free medium to reduce the content of residual 2,4-D in the tissue. This callus was then transferred to solid medium supplemented with various levels of 2,4-D. Growth of this callus was best at the $2.0 \mathrm{mg}$ /liter concentration (Table 3). Moderate growth was achieved at the $0.5,1.0$, and $5.0 \mathrm{mg} /$ liter concentrations, but concentrations below $0.1 \mathrm{mg} /$ liter failed to stimulate growth beyond that occurring in the culture without added 2,4-D. With sweetclover root-derived callus grown on a somewhat different basal medium, ElHinnawy (4) found that growth was best at a 2,4-D concentration of $1 \mathrm{mg} /$ liter.

Kinetin concentrations of 0.5 and $1.0 \mathrm{mg}$ /liter were tested in combination with 2,4-D concentrations of 0.01 and $2.0 \mathrm{mg} /$ liter for effect on growth of C2MY callus. When the 2,4-D concentration was $2.0 \mathrm{mg} /$ liter, kinetin did not affect the growth ratio. However, at the $0.01 \mathrm{mg} /$ liter level of 2,4-D, kinetin at $0.5 \mathrm{mg} /$ liter resulted in a small but significant increase 
Table 5. Influence of groups of amino acids on growth ratio of CIMY and C4MY callus (three replications, cultured 28 days). Initial fresh weights were approximately $100 \mathrm{mg}$.

\begin{tabular}{ccc}
\hline & \multicolumn{2}{c}{ Growth ratio } \\
\cline { 2 - 3 } Amino acid group $\dagger$ & C1MY & C4MY \\
\hline 1 & $7.1 \mathrm{~d}^{*}$ & $4.7 \mathrm{~d}^{*}$ \\
2 & $7.7 \mathrm{~d}$ & $5.1 \mathrm{~d}$ \\
3 & $9.2 \mathrm{c}$ & $7.0 \mathrm{~b}$ \\
4 & $6.4 \mathrm{~d}$ & $4.0 \mathrm{e}$ \\
5 & $12.0 \mathrm{~b}$ & $5.8 \mathrm{c}$ \\
6 & $18.9 \mathrm{a}$ & $8.4 \mathrm{a}$ \\
No supplement & $6.4 \mathrm{~d}$ & $4.6 \mathrm{~d}$ \\
\hline
\end{tabular}

* Within the same strain, numbers followed by the same letter are not significantly different at the $5 \%$ probability level. † Composition of amino acid groups: Group 1-DL-alanine, glycine, DL-valine, L-cysteine, and DL-methionine; Group 2-L-aspartic acid, DL-threonine, DL-serine, DL-isoleucine, and L-tryptophan; Group 3-L-arginine, L-histidine, L-proline, L-glutamic acid, and Lphenylalanine; Group 4-L-leucine L-lysine, and L-tyrosine; Group 5-All 18 amino acids; Group 6-Casein hydrolysate. Concentration of each individual amino acid was $50 \mathrm{mg} / \mathrm{liter}$ and that of casein hydrolysate was $900 \mathrm{mg} /$ liter.

in growth ratio, and the $1.0 \mathrm{mg}$ /liter kinetin level was slightly superior to the $0.5 \mathrm{mg}$ /liter concentration.

In a comparison of IAA, NAA, and 2,4-D at $2 \mathrm{mg} /$ liter, IAA and NAA failed to stimulate callus growth. A mixture of kinetin and NAA was similarly ineffective. Under the conditions used, only 2,4-D was highly effective in stimulating the growth of sweetclover callus.

Response to Sucrose. Callus of the C1MY strain was tested for response to sucrose concentrations ranging from 0.25 to $8.0 \%$. The callus used for inoculation was held for 10 days on a medium containing all usual constituents except sucrose. Highest growth ratios were achicved at sucrose concentrations of 2 or 30 ; concentrations both above and below these levels were significantly less favorable (Table 4). With callus from sweetclover root tissue, ElHinnawy (4) found that a sucrose concentration of $2 \%$ was superior to concentrations of $1 \%$ or lower or $4 \%$ or higher. In comparing sucrose with other carbohydrates at the 2\% level, he observed that sucrose was somewhat less effective than raffinose but more effective than glucose, mannose, or starch.

Response to Amino Acids. Preliminary trials indicated that sweetclover callus grew appreciably better in at medium containing casein hydrolysate (C.H) at 1 g/iter than in a medium containing no organic nitrogen. In tests to determine whether this enhanced growth could be attributed to a small group of amino acids, growth effects of four groups of amino acicls, totaling 18 amino acids, were compared with the effects of all 18 amino acids together, and of $\mathrm{CH}$. The groupings (1 lable 5) took into account the observation of Harris (9) that in cultures of oat embryos, L-phenylalanine and I-tyrosine were antagonistic to each other, as were L-leucine and DL-valine, DL-isoleucine and DL-valine, and L-arginine and L-lysine.

As shown in 'Table 5, both callus strains tested grew best in the medium containing CH. Treatments 5 (all 18 amino acids) and 3 (arginine, histidine, proline, glutamic acid, and phenylalanine) were second and third best for strain CIMY and third and second best for C4MY. Amino acid groups 1, 2, and 4 were no better than the control (no added amino acids) for cither of the callus strains. The growth of strain
Table 6. Influence of aspartic (asp) and glutamic (glu) acids on growth ratio of CIMY and C4MY callus (five replications, cultured 28 days). Initial fresh weights were approximately $100 \mathrm{mg}$.

\begin{tabular}{lcc}
\hline & \multicolumn{2}{c}{ Growth ratio } \\
\cline { 2 - 3 } Amino acid & C1MY & C4MY \\
\hline Asp (100 mg/liter) & $6.6 \mathrm{~d}^{*}$ & $7.1 \mathrm{c}$ \\
Glu (100 mg/liter) & $16.1 \mathrm{c}$ & $10.5 \mathrm{~b}$ \\
Asp and Glu (50 mg of each/liter) & $17.6 \mathrm{~b}$ & $10.8 \mathrm{ab}$ \\
Casein hydrolysate (900 mg/liter) & $21.2 \mathrm{a}$ & $11.7 \mathrm{a}$ \\
No supplement & $6.0 \mathrm{~d}$ & $7.1 \mathrm{c}$ \\
\hline
\end{tabular}

* Numbers followed by the same letter are not significantly different at the $5 \%$ probability level.

Table 7. Influence of 2,4-D concentration on counts of single cells and visible cell clumps in C2MY suspension cultures (means $\pm S E$, three replications, cultured 14 days).

\begin{tabular}{ccc}
\hline $2,4-\mathrm{D}$ concentration & Single cells & Cell clumps (no./culture) \\
\hline mgliter & millions/ml & \\
0 & $3.92 \pm 0.07$ & $\ldots+$ \\
0.2 & $2.76 \pm 0.07$ & $35.7 \pm 1.3$ \\
0.8 & $0.37 \pm 0.06$ & $42.3 \pm 2.1$ \\
2.0 & & $66.0 \pm 2.5$ \\
\hline
\end{tabular}

$\dagger$ No survival.

G1MY was better than that of C4MY on all media included in this experiment.

These results strongly suggested that the effect of C.H could not be attributed wholly to any single amino acid or small group of amino acids. With tobacco callus, on the other hand, Sandstedt and Skoog (15) reported that the stimulative activity of a complex amino acid mixture was due to its content of aspartic and glutamic acids. Because these two amino acids were in! separate groups in the foregoing test, an experiment was done in which aspartic acid and glutamic acid were tested alone and in combination. In this experiment, the mixture of the two amino acids was almost as effective as CH for both C1MY and CAMY, and for each strain glutamic acid alone was almost as effective as the mixture of both amino acids (Table 6). Aspartic acid alone did not appear to stimulate growth. On the basis of these results it is reasonable to conclude that glutamic acid is primatrily responsible for the stimulatory effect of amino acid treatment 3 (Table 5) and that this amino acid is probably more important than any other single amino acid in accounting for the effect of $\mathrm{CH}$.

\section{Growth of Cells in Suspension Culture}

Effects of 2,4-D Concentration and Shaking Treatment. Portions of C2MY callus of uniform size (about $100 \mathrm{mg}$ fresh weight) were transferred to liquid medium containing various levels of 2,4-D. These suspension cultures were shaken during incubation, either on a reciprocating shaker at $100 \mathrm{cycles} / \mathrm{min}$ or on a Gyrotory shaker at $160 \mathrm{rpm}$. Results for the cultures incubated on the reciprocating shaker are shown in Table 7 . In the absence of aclded 2,4-D, cells failed to survive in these cultures. In the 2,4-D concentration range between 0.2 and $2.0 \mathrm{mg} /$ liter, counts of single cells decreased and counts of cell clumps increased with increasing concentration of 
2,4-D. Compared with cultures incubated on the reciprocating shaker, those incubated in the Gyrotory shaker (results not shown) produced somewhat higher counts of single cells and somewhat lower counts of cell clumps. However, both shaking treatments appeared satisfactory for the growth of suspension cultures.

The cultures from the $0.2,0.8$, and $2.0 \mathrm{mg}$ /liter 2,4-D concentrations (foregoing paragraph) were separately filtered through a stainless steel screen (125 micron mesh) to remove cell clumps. Many single cells also were removed in this process; thus, cell counts in the filtrates were substantially reduced from levels in the unfiltered cultures. Microscopic examination of the filtrates indicated that each contained about $90 \%$ free cells, with the remaining cells occurring as small clumps of 3 to 10 cells. Spent cell-free medium of the corresponding type was used to dilute portions of the filtered cell suspension so that each contained approximately $4 \times 10^{5}$ cells $/ \mathrm{ml}$. Aliquots $(10 \mathrm{ml})$ of these adjusted suspensions were used to inoculate $30-\mathrm{ml}$ portions of fresh medium with 2,4-D concentrations corresponding to those in the inocula. Thus, initial cell counts in these cultures were approximatcly $10^{5}$ cells $/ \mathrm{ml}$. After 14 days with either of the two shaking treatments, cell counts ranged from about $2 \times 10^{5}$ cells $/ \mathrm{ml}$ at $2.0 \mathrm{mg} 2.4-\mathrm{D} /$ liter to $10^{6}$ cells $/ \mathrm{mI}$ at the $0.2 \mathrm{mg} /$ liter $2,4-\mathrm{D}$ concentration. EIHinnawy (3) observed that chelating agents caused an increase in numbers of free cells in swectclover suspension cultures. The present study indicates that a similar effect can be obtained by lowering the concentration of 2,4-D in the medium. The medium used by ElHinnawy contained $2,4-\mathrm{D}$ at $1 \mathrm{mg} / \mathrm{liter}$, which contrasts with the $0.2 \mathrm{mg} /$ liter level that appeared most favorable for single-cell production in this study.

Suspension Cultures Derized from Various Callus Types. It seemed possible that the callus types designated as friable (Table 2) might give rise to suspension cultures with comparatively high counts of single cells. To investigate this possibility, portions (about $100 \mathrm{mg}$ ) of C2MYY, C3W-friable, H4W-friable, and C5W-friable callus were transferred to liquid medium containing $0.2 \mathrm{mg} /$ liter of 2,4-D. The suspensions were incubated for 15 days on the Gyrotory shakes. (160 rpm), after which cell clumps were filtcred out as previously described. Each filtrate was sampled for an initial cell count, and $10-\mathrm{ml}$ aliquots of each were then used to inoculate 80 -ml portions of fresh medium. These cultures were incubated for 15 days on the reciprocating shaker $(100$ cycles $/ \mathrm{min})$ after which final cell counts were made. Cell counts for strain $\mathrm{C} 5 \mathrm{~W}$-friable were approximately double the values observed for the other three strains. Even though values for the other two friable strains were not greatly different from those for C2MY, it is apparent that not all strains exhibiting the friable growth type on agat yield the highest counts of single cells when grown in suspension culture.

Effects of Inoculum Size and Duration of Incubation. Filtrates containing primarily single cells were prepared for strains $\mathrm{C} 5 \mathrm{~W}$-friable and $\mathrm{H} 4 \mathrm{~W}$-triable. Each filtrate contained about $4 \times 10^{5}$ cells $/ \mathrm{ml}$. One- and $10-\mathrm{ml}$ portions of these filtrates were used to inoculate 39 - and $30-\mathrm{ml}$ portions, respectively, of fresh medium. Thus, dilutions of the filtrates were 1:40 and 1:4, and initial cell densities were about $10^{4}$ and $10^{5}$ cells $/ \mathrm{ml}$, respectively. Cultures were incubated on the reciprocating shaker (100 cycles/min), and counts of single cells were made every 5 days over a 25-day period. In the cultures with the higher initial cell density (HICD), the cell count doubled in 5 days, but in those with the lower initial cell density (LICD), between 10 and 15 days were required for the cell count to double. The difference in final/ initial cell-count ratio between HICD and LICD cultures was at least twofold until the 25-day sampling, at which time the I.ICD cultures, with a ratio of about 20, were only slightly below the HICD cultures, with values of about 22 . Street (17) cites a number of examples of the pronounced effect of "conditionel" medium on the growth of suspension cultures. The differences in lag period between LICD and HICD cultures were probably due, at least in part, to the larger quantity of conditioned medium in the latter.

The regeneration of plants from cultured cells and tissues must be achieved if these cultures are to be used most effectively in plant breeding programs. Various regenerative procedures were tried, inclucling among others the methods successfully used by Saunders and Bingham (16) for the regeneration of alfalfa (Medicago sativa L.) plants. Abundant root formation occurred in some of the media, but no complete plants have been obtained thus far. Although the conditions for regeneration of plants have not been defined, the present study has provided a definition of conditions required for satisfactory growth of sweetclover callus and suspension cultures. These cultures already have been useful in certain biochemical and cytological experiments, and further use of such cultures in studies of these and other types appears promising.

\section{REFERENCES}

1. Blaydes, D. F. 1966. Interaction of kinetin and various inhibitors in the growth of soybean tissue. Physiol. Plant. 19: $748-753$.

2. Bottino, P. J. 1975. The potential of genetic manipulation in plant cell cultures for plant breeding. Radiat. Bot. 15:1-16.

3. FlHinnawy, F. 1974. Chelating compounds as cell wallloosening agents in cell suspension cultures of Melilotus alba. Desr. 7. Pflanzenphysiol. 71:207-219.

4. - - 1974. Fffects of some growth regulating substances and carbohydates on chlorophyll production in Melilotus alea (Desr.) callas tissue cultures. Z. Pflanzenphysiol. 74: $9 ;-10 \%$

5. Fox, J. E. 1963. Growth factor requirements and chromo. some number in tobacco tissue culture. Physiol. Plant. 16: $793-803$.

6. Gamborg, O. L. 1966. Aromatic metabolism in plants. II. Enzymes of the shikimate pathway in suspension cultures of planil cells. Can. J. Biochem, 44:791-799.

7. Congenbach, B. G., F. A. Haskins, and H. J. Ciorz. 1969. Genetic studies of induced mutants in Melilolus alba. I. shorl-internode dwaif, curled leaf, multifoliolate leaf, and cotyledonary branching. Crop Sci. 9:607-610.

8. Corz. H. J., and F. A. Haskins. 1969. Absence of dominance of the cu gene in influencing o-hydroxycinnamic acid content in Molilotus alba. Crop Sci. 9:79-81.

9. Harris. (i. P. 1956. Amino acids as sources of nitrogen for the growth of isolated oat embryos. New Phytol. 55:253-268. 
10. Haskins, F. A. and H. J. Gorz. 1965. Absence of dominance of the $B$ gene in influencing $\beta$-glucosidase activity in Melilotus alba. Genetics 51:733-738.

11. LaRue, T. A. G. and O. L. Gamborg. 1971. Ethylene production by plant cell culcures. Pl. Physiol. 48:394-398.

12. Linsmaier, F. M. and F. Skoog. 1965. Organic growth factor requirements of tobacco tissue cultures. Physiol. Plant. 18 : 100-127.

13. Nickell, L. G. 1952. Tissue culture studies on plant tumors caused by virus. Torreva 79:264-265.

14. - - - - and W. Tulecke. 1959. Responses of plant tissue cultures to gibberellin. Bot. Gaz. 120:245-250.
15. Sandstedt, R. and F. Skoog. 1960. Effects of amino acid components of yeast extract on the growth of tobacco tissue in vitro. Physiol. Plant. 13:250-256.

16. Saunders, J. W. and E. T. Bingham. 1972. Production of alfalfa plants from callus tissue. Crop Sci. 12:804-808.

17. Street, H. E. 1973. Chapters I and 4 in H. E. Street (ed.) Plant tissue and cell culture. Univ. of California Press, Berkeley and Los Angeles.

18. - - - and S. M. McGregor. 1952. The carbohydrate nutrition of tomato roots. III. The effect of external sucrose concentration on the growth and anatomy of excised roots. Ann. Bot. 16:185-205. 